This document is the accepted manuscript version of the following article:

Giannoukos, S., Lee, C. P., Tarik, M., Ludwig, C., Biol1az, S., Lamkaddam, H., ... S1owik, J. (2020). Real-time detection of aerosol metals using online extractive electrospray ionization mass

spectrometry. Analytical Chemistry, 92(1), 1316-1325. https://doi.org/10.1021/acs.analchem.9b04480

\title{
Real-time detection of aerosol metals using on-line extractive electrospray ionization mass spectrometry
}

\author{
Stamatios Giannoukos, ${ }^{\mathrm{a}, \mathrm{b}, *}$ Chuan Ping Lee, ${ }^{\mathrm{a}}$ Mohamed Tarik, ${ }^{\mathrm{b}}$ Christian Ludwig, ${ }^{\mathrm{b}, \mathrm{c}}$ Serge \\ Biollaz, ${ }^{b}$ Houssni Lamkaddam ${ }^{a}$, Urs Baltensperger ${ }^{a}$, Andre Stephan Henry Prevot, ${ }^{a}$ and Jay \\ Slowik ${ }^{\mathrm{a}, *}$ \\ a Laboratory of Atmospheric Chemistry, Paul Scherrer Institute (PSI), 5232 Villigen PSI, Switzerland \\ ${ }^{b}$ Bioenergy and Catalysis Laboratory, Paul Scherrer Institute (PSI), 5232 Villigen PSI, Switzerland \\ ${ }^{c}$ Engineering (ENAC), École Polytechnique Fédérale de Lausanne (EPFL), CH 1015 Lausanne, Switzerland.
}

*Corresponding authors: Stamatios Giannoukos (stamatios.giannoukos@psi.ch), Jay G. Slowik (jay.slowik@psi.ch)

Keywords: metal particles, EESI, mass spectrometry, TOF-MS, air quality, environment.

\section{ABSTRACT}

Metal emissions are of major environmental and practical concern due to their highly toxic effects on human health and ecosystems. Current technologies available in the market for their detection are typically limited by time-resolution of 1 hour or slower (e.g. via semicontinuous X-ray fluorescence measurements) or non-quantitative (e.g. laser ablation mass spectrometry). In this work, we report the development of a novel technique for the real-time detection and monitoring of metal particles in-situ using an extractive electrospray ionization (EESI) source coupled to a high-resolution time-of-flight mass spectrometer (TOF-MS). The experiments were conducted in the negative ionization mode using disodium ethylenediamine tetraacetic acid (EDTA) dihydrate to chelate with metals and form stable metal complexes. Results for water-soluble metal compounds were obtained. The following representative metal ions were examined: $\mathrm{Pb}, \mathrm{Cd}, \mathrm{Zn}, \mathrm{Ce}$ (III), $\mathrm{Ba}, \mathrm{Ni}, \mathrm{Fe}$ (II), $\mathrm{Fe}$ (III), $\mathrm{Cu}$ (II), $\mathrm{Cr}$, Mo, Co (II), Mg, Nd, Li, Ti, Ca, Cs, Ag, Tm, Er (III), La (III), Yb (III), Eu (III), Pr (III), Gd (III), Lu (III), Dy (III), Tb (III), Ho and Ru (III). Results showed very good linear mass response $\left(R^{2} 0.9983\right)$, low $\mathrm{ng} / \mathrm{m}^{3}$ limits of detection (LoD) and fast response times $(1 \mathrm{sec})$. The stability and repeatability of the developed EESI-TOF-MS was tested under complex dynamic and periodic experimental conditions and negligible matrix effects were measured for internally and externally mixed metal particles. Benchmark testing against inductively coupled plasma mass 
spectrometry (ICP-MS) was also performed highlighting on-line measurement capabilities of aerosol metals with LOD lower than those of the ICP-MS. Proof-of-concept ambient measurements were performed in New Delhi, India and very promising results were obtained allowing further exploitation elsewhere.

\section{INTRODUCTION}

Emissions of particulate metals and trace elements in energy conversion and industrial processes are common but a major concern for the environment and process stability. Many metals are highly toxic, with detrimental effects on human health and ecosystems [1-5]. In addition, in power plants utilizing gasification, emissions of certain metals during this process are known to compromise downstream equipment, fouling reactors and catalysts used for product synthesis [6]. Catalyst poisoning can also degrade engine after treatment systems used to remove organic gases [7]. The determination of particulate metals in ambient air is also of high importance. Toxic metals in particulate matter (PM) can cause a wide range of adverse health effects, diseases and disorders including respiratory and pulmonary disorders, Alzheimer, neurotoxicity, cancer or even death $[3-5,8]$. Possible human exposure pathways comprise all means of primary contact with contaminated air, water or soil. The sources of atmospheric trace elements are often transient or highly time-variable. Emissions of particulate metals in the ambient air are complex and still not well understood mainly due to technical limitations arising either from the characteristics of the analytical instrumentation or the detection approaches that do not allow precise and systematic data collection and analysis [9-13]. Assessing the sources of these emissions and determining reduction strategies or proposing control policies requires sensitive, robust, highly time-resolved qualitative and quantitative measurement techniques [14].

Metal particles in the ambient atmosphere originate both from natural sources such as mineral dust and anthropogenic sources such as industrial emissions (e.g. mineral extraction, coal-burning power plants, combustion by-products, solid waste incineration, metal processing and welding facilities, waste incinerators, etc.), and vehicular emissions [15-18]. Current methodologies for the detection and quantification of metals in energy conversion and environmental systems rely on sample collection on filters for off-line analysis by techniques such as gas chromatography or liquid chromatography combined with mass 
spectrometry (GC-MS or LC-MS), inductively coupled plasma coupled to either optical emission spectrometry or mass spectrometry (ICP-OES or ICP-MS) $[19,20]$, while atmospheric sampling has in addition utilized other techniques such as X-ray fluorescence (XRF) and particle-induced X-ray emission (PIXE) [21, 22]. Membrane inlet mass spectrometry (MIMS) with charge exchange ionization has also shown detection capabilities of organometallic compounds such as ferrocene and molybdenum hexacarbonyl in the gas phase, however it cannot detect low volatility metal particles [23]. The above techniques require timeconsuming sampling, sample transportation and preparation processes suffering from a lack of time-resolved chemical information, which is not adequate for many applications (e.g. process and emission monitoring). Most commercially available instruments do not suffice to perform real-time analysis, while sample contamination, loss or alteration of the sampled materials during transportation back to the lab for analysis is possible.

Portable instrumentation available in the market for on-site detection of metals in particulate matter are still limited. The state-of-art Xact ${ }^{\circledR} 625 \mathrm{i}$ ambient continuous multimetals monitor (Cooper Environmental Services LLC) is based on energy dispersive X-ray fluorescence (EDXRF) spectroscopy [24-27]. Sampling and analysis of approximately 32 metals vary from 15 up to 240 minutes giving detection limits in the range of sub $\mathrm{ng} / \mathrm{m}^{3}$. Despite of the low LoDs, its minimum time resolution of 15 minutes does not allow the on-line detection and monitoring of rapid evolutions of atmospheric events of metal emissions in real-time. However, detection of certain elements under atmospheric conditions is prevented by lamp energy and atmospheric gas interference (e.g. Li, Mg) or elemental interferences (e.g. Co, $\mathrm{Na}$ ). The Aerodyne aerosol mass spectrometer (AMS) has also been reported to detect particulate lead in and around Mexico City, whereas an online thermal-desorption electron ionization high resolution time-of-flight AMS has been utilized in the same area to measure $\mathrm{Cu}, \mathrm{Zn}, \mathrm{As}$, $\mathrm{Se}, \mathrm{Sn}$ and Sb in ambient samples [15]. The soot particle (SP)-AMS provides information of the chemical and physical properties of refractory black carbon particles including metal nanoparticles (e.g. aluminum, zinc, silver and gold) [28].

To overcome limitations of the existing analytical technologies for on-site chemical analysis, portable extractive electrospray ionization (EESI) mass spectrometry could be used [29 - 38]. EESI is an ambient environment soft ionization technique that combines the advantageous characteristics of electrospray ionization (ESI) with real time chemical analysis. Aerosol 
particles are continuously sampled through a multi-channel denuder into the EESI source and intersect with a highly charged spray of a solvent or a mixture of solvents (e.g. water, methanol, acetonitrile, etc.) generated by a conventional electrospray capillary. Soluble components are extracted into the spray and ionized by the Coulomb explosion method before detection by the TOF-MS. The advantageous characteristics of the EESI start with the fact that the sample analytes are not directly mixed with the ESI solvent, but their streams intersect prior to their introduction into the vacuum system. This eliminates the need for separated sampling/analysis stages, allowing direct, real-time analysis. So far, EESI mass spectrometry has been successfully employed in the analysis of a wide range of both simple and complicated organic and inorganic samples originating from biological and environmental sample sources [31-35] and it has also been applied for the detection of toxic and hazardous chemicals in food industry $[36,37]$. Conventional electrospray ionization systems have also been used in the negative ion mode to detect metal complexes using hydrochloric acid or nitric acid [39], as well as with chelating agents such as dicationic, tricationic, or tetracationic ion-pairing reagents, which form positively charged complexes with the metal ions, enabling their detection in the positive ion mode $[40,41]$.

In this study and for the first time, a built-in-house EESI source coupled to a field deployable high-resolution time-of-flight mass spectrometer (EESI-TOF-MS) [30] was adapted, tested, optimized, characterized and validated for the detection of water-soluble metal compounds and trace elements. The developed methodology was benchmarked against a commercial ICP-MS, and was used during a field campaign in an urban environment (New Delhi, India) to detect and study events of metal emissions in real-time.

\section{EXPERIMENTAL PROCEDURE}

\subsection{Motivation and concept}

The motivation behind this research is to develop a high-throughput analytical methodology that will allow the real-time detection and on-line monitoring of metal particles in energy conversion systems and environmental applications using a novel ambient environment ionization source (EESI) coupled to a high resolution field-deployable MS (Figure 1a). The online chemical analysis capabilities of the EESI-TOF-MS will allow the chemical characterization of events, processes and phenomena in real-time allowing fast decision 
making at the point of analysis. Target metal-containing compounds that were selected to be examined in this work are presented in Table S1 (in supporting information (SI)). These compounds dissolve in water allowing us to nebulize them and generate metal-containing aerosol particles. The compounds in Table S1 are presented in ascending order of molecular weight and most of the metals in this list are potentially toxic for human health and the ambient environment and a threat for industrial processes. Here, we determine the performance and the capabilities of our newly developed system to detect these metals.

\subsection{Chemicals}

Ethylenediaminetetraacetic acid (EDTA) disodium salt dehydrate (99.0-101.0\% titration) and 34 water-soluble metal compounds of Table S1 were purchased from Sigma Aldrich Chemie $\mathrm{GmbH}$, Buchs, SG. Copper (II) sulfate (4 \% (w/v) (prepared from copper (II) sulfate pentahydrate)) was also purchased from Sigma Aldrich Chemie GmbH (Buchs, SG.) and was provided in the liquid phase. Methanol (ultrapure for spectrophotometric grade, $(>99.8 \%$ of purity) was provided by Fisher Scientific AG. CH. Ultrapure water (18.2 MOhm cm, totalorganic carbon less than $2 \mathrm{ppb}$ ) was obtained from a Milli-Q water purification system (Merck). High purity synthetic air was provided by Air Liquide.

\subsection{EESI-TOF}

Metal particle detection and monitoring experiments were performed using an EESI-TOF supplied by TOFWERK AG, Thun, Switzerland, which was previously demonstrated for organic aerosol detection [30]. The system used herein is essentially identical in terms of hardware [30], with the identity of the working solution (spray composition) and polarity of the EESI source being the key differences. The latest increases the system's utility and is an important advantage of the approach. The EESI-TOF-MS consists of the following main components: a) an EESI source, b) an atmospheric pressure inlet (API)-TOF-MS [42], c) the vacuum system (screw pump and turbomolecular pump) and d) a computer for data acquisition and interpretation. The whole assembly of the EESI-TOF-MS (low weight and size) allow its portability, making it an ideal tool for in-situ analytical applications. 
The EESI source consists of a stainless steel (SS) cylindrical chamber with a volume of 120 $\mathrm{mm}^{3}$. Prior to this chamber, a $18 \mathrm{~mm}$ long chamber with $35 \mathrm{~mm}$ inner diameter hosts an activated charcoal multichannel denuder (with length of $36 \mathrm{~mm}$ and diameter of $16 \mathrm{~mm}$ ). The denuder reduces gases concentrations and at the same time provides a laminar stable sample flow (at $1 \mathrm{~L} / \mathrm{min}$, room temperature). The EESI source consists of a highly charged (using a corona cable) working fluid stored in a $100 \mathrm{~mL}$ Duran laboratory bottle. A high accuracy microfluidic flow controller (MFCS ${ }^{\mathrm{TM}}$-EZ, Fluigent Deutschland $\mathrm{GmbH}$, Germany) provides a stable flow of the working solution. Depending on the dimensions of the ESI capillary (ID and length) and its condition (e.g. straight, bended, stable or unstable position), the conductivity and viscosity of the working solution, the applied flow and the applied electric field, the EESI source can generate a stable Taylor cone-jet providing a high number of charged droplets which extract and ionize the sample aerosols.

The EESI working solution and polarity determine the set of detectable analytes. Here we use a 50:50 water:methanol solution doped with 100 ppm EDTA disodium salt dehydrate. EDTA was selected because it chelates strongly with a wide range of metal ions of different oxidation states and forms stable 1:1 complexes with metals. The water/methanol solution, for the experimental conditions that we established (dimensions of the ESI capillary, EESI solution flow, etc.), provided a stable electrospray signal, cleaner mass spectrum (compared to water/acetonitrile) - reduced background and very good extraction of metals in the EESI charged spray. The charged droplets collide with the sampled aerosol particles, yielding droplets containing analyte material. These charged droplets were introduced into the TOF$\mathrm{MS}$ at $1 \mathrm{~L} / \mathrm{min}$ via a SS inlet capillary with length of $70 \mathrm{~mm}$ and inner diameter of $0.5 \mathrm{~mm}$. The inlet capillary was tightly fitted within a conical manifold made of aluminium and was heated constantly at $275^{\circ} \mathrm{C}$, although the short residence time in the inlet capillary results in the droplets experiencing a much lower effective temperature. Evaporation of the droplets causes ejection of ions, where we detect the analyte metals as negatively-charged complexes with EDTA. The API-TOF-MS has been described in detail previously elsewhere [42].

\subsection{Sample preparation and introduction}

Two different sample introduction techniques were applied to evaluate the robustness and the performance of the developed methodology. In both cases, aerosols were produced by 
nebulization and drying of an aqueous solution containing a metal cation and corresponding anion. For the first approach, the sample solution was prepared at a single concentration and the aerosol concentration controlled by dilution with a synthetic air dilution flow (Figure 1b). For the second approach, solutions of different concentrations were prepared and nebulized without an additional dilution flow. The two methods are described in detail in the SI.

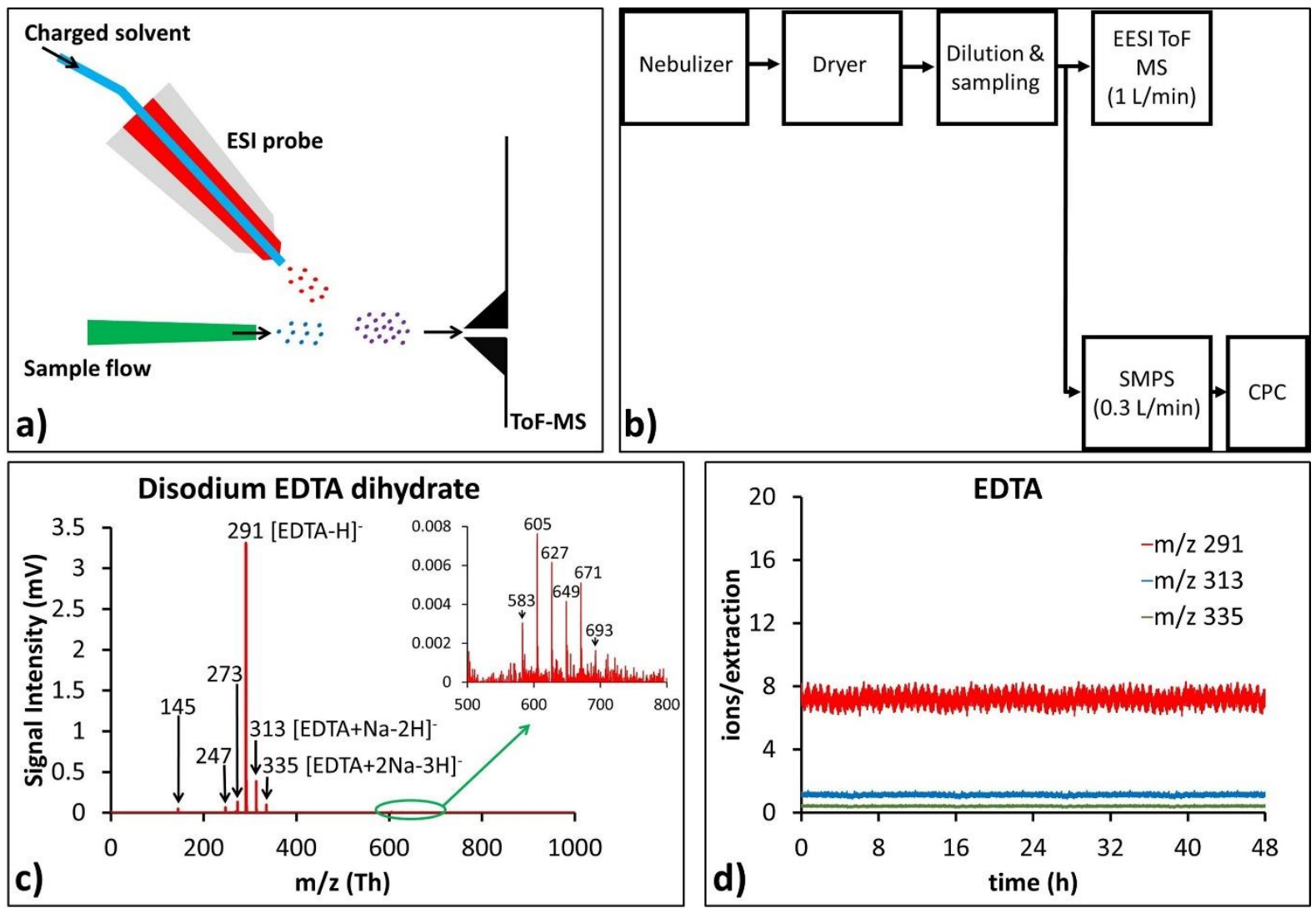

Figure 1. a) Operation concept of the EESI-TOF. Sampled particles intersect with a stream of charged droplets and are extracted into the TOF-MS, b) Graphical representation of the experimental setup used in our experiments, c) EESI-TOF mass spectrum of disodium EDTA dihydrate, d) stability test of the electrospray ions [EDTA-H]', [EDTA+Na-2H] and [EDTA+2Na$3 \mathrm{H}]^{-}$from EDTA over a period of $48 \mathrm{~h}$.

\section{RESULTS AND DISCUSSION}

\subsection{EESI-TOF experiments.}

A typical EESI mass spectrum of disodium EDTA acquired during our experiments is shown in Figure 1c. The main peaks of the disodium EDTA are detected at the following mass-to-charge ratio $(\mathrm{m} / \mathrm{z}): 291,313$ and 335 . Precisely, the mass fragment 291.08 corresponds to the 
deprotonated EDTA ([EDTA-H] $\left.]^{-}\right)$, the ion 313.06 is assigned to the [EDTA $\left.+\mathrm{Na}-2 \mathrm{H}\right]-$ and the ion 335.05 corresponds to the [EDTA+2Na-3H]-. The ratio among these three ions based on peak area is 1: $0.16: 0.06$. The mass fragment 145.04 corresponds to the $\left[\right.$ EDTA-2H] ${ }^{2-}$. The ratio between the deprotonated EDTA and the [EDTA-2H] ${ }^{2-}$ is 70:1. The peak 273 corresponds to the deprotonated EDTA that has lost a molecule of $\mathrm{H}_{2} \mathrm{O}$ and the peak 247 is assigned to the deprotonated EDTA that has lost a molecule of $\mathrm{CO}_{2}$. The peaks 583, 605, 627, 649, 671 and 693 correspond to [2EDTA - H] , , [2EDTA + Na - 2H]', [2EDTA + 2Na - 3H]', [2EDTA + 3Na - 4H] $]^{-}$ , $[2 \mathrm{EDTA}+4 \mathrm{Na}-5 \mathrm{H}]^{-}$and $[2 \mathrm{EDTA}+5 \mathrm{Na}-6 \mathrm{H}]^{-}$respectively. The ratio among the deprotonated EDTA and the [2EDTA $-\mathrm{H}^{-}$which is the most abundant in the mass range between 500 and 1000 is $1200: 1$. Figure $1 d$ presents the stability of the electrospray ions of the disodium EDTA (291, 313 and 335) over a time window of 48 hours. For $1 \mathrm{~Hz}$ time resolution, the relative standard deviation RSD \% of the mass peak 291 was calculated to be $9.8 \%$.

As described above, a series of water-soluble solutions were prepared at various concentrations and introduced into the EESI source for ionization. Figure 2 presents representative mass spectra obtained for zinc, lead, barium and cadmium salts. During all tests, we obtained a total ion current (TIC) of approximately 500,000 cps and about 26 ions/extraction. Zinc has five stable natural isotopes: ${ }^{64} \mathrm{Zn},{ }^{66} \mathrm{Zn},{ }^{67} \mathrm{Zn},{ }^{68} \mathrm{Zn}$, and ${ }^{70} \mathrm{Zn}$ with natural abundances of $49.2 \%, 27.7 \%, 4 \%, 18.5 \%$ and $0.6 \%$ respectively. The inset in Figure $2 a$ presents an EESI-TOF mass spectrum of $Z n$. The peaks at $m / z$ 353, 355, 356, 357 and 359 can be easily identified and correspond to the following complexes [EDTA $+{ }^{64} \mathrm{Zn}-3 \mathrm{H}$ ], [EDTA $+{ }^{66} \mathrm{Zn}$ $-3 \mathrm{H}]^{-},\left[\mathrm{EDTA}+{ }^{67} \mathrm{Zn}-3 \mathrm{H}\right]^{-}$, [EDTA $\left.+{ }^{68} \mathrm{Zn}-3 \mathrm{H}\right]^{-}$and [EDTA $\left.+{ }^{70} \mathrm{Zn}-3 \mathrm{H}\right]^{-}$, respectively. The intensity ratio of the experimentally detected peaks is 1: 0.56: 0.07: 0.38: 0.01 which is in good agreement with the ratio of the natural abundances of the isotopes of $\mathrm{Zn}(1: 0.56: 0.08: 0.38$ : 0.01). We also observed signal at $m / z 176,177,177.50,178$ and 179 , which correspond to the doubly-charged complexes of $\left[\text { EDTA }+{ }^{64} \mathrm{Zn}-4 \mathrm{H}\right]^{2-}$, [EDTA $\left.+{ }^{66} \mathrm{Zn}-4 \mathrm{H}\right]^{2-},\left[\mathrm{EDTA}+{ }^{67} \mathrm{Zn}-4 \mathrm{H}\right]^{2-}$, $\left[\text { EDTA }+{ }^{68} \mathrm{Zn}-4 \mathrm{H}\right]^{2-}$ and $\left[\text { EDTA }+{ }^{70} \mathrm{Zn}-4 \mathrm{H}\right]^{2-}$. The ratio among these doubly charged peaks matches the isotopic ratios of the singly-charged peaks, although the relative intensity of the doubly-charged series is very low ( $0.6 \%$ compared to the singly-charged peaks). Figures $2 \mathrm{~b}$ to $2 \mathrm{~d}$ likewise show metal complexes with EDTA-3H for singly charged ions, with all detected isotope ratios in good agreement with their natural abundances. The ratio of doubly-to-singly charged ions varies with the metal, but is always very low $(0.6 \%$ for $\mathrm{Pb}, 0.7 \%$ for $\mathrm{Ba}, 0.6 \%$ for $\mathrm{Cd}$ ). 
Similar results were obtained for a wide range of metal compounds as shown in Table S2 (in the SI). In Table S2 water-soluble metal containing compounds tested with our EESI-TOFMS are both sorted by ascending atomic weight and classified by ascending oxidation state (I to III). We report the main ion observed for each compound as well as all stable isotopes. The isotopes are sorted from the most abundant to the least abundant. In the same order, we present their natural and experimentally obtained isotopic ratio distribution with the most abundant peak (main $\mathrm{m} / \mathrm{z}$ ) normalized to 1 and the remaining isotopes normalized to the former. During the experiments, we observed that when EDTA reacts with a metal (M) compounds from the first oxidation state, it loses $2 \mathrm{H}$ and produces complexes with the formula [EDTA+ $\left.{ }^{{ }} \mathrm{M}(\mathrm{I})-2 \mathrm{H}\right]{ }^{-}$. Metals belonging to the second oxidation state form [EDTA+ ${ }^{{ }} \mathrm{M}$ (II) $-3 \mathrm{H}]^{-}$complexes, whereas, for metals from the third oxidation state we observed a loss of $4 \mathrm{H}$ and the detected metal complexes had the formula [EDTA+ ${ }^{\mathrm{X}} \mathrm{M}$ (III) $\left.-4 \mathrm{H}\right]$. The above indicates that the oxidation state in which a metal compound exists, plays a major role in the chelation with EDTA. However, when we tested iron (II) sulfate heptahydrate and iron (III) chloride hexahydrate, iron was detected (in both cases) at the same $\mathrm{m} / \mathrm{z}$ of 344 . This could indicate an electrochemical process occurring in the EESI source (e.g. oxidation of iron (II) to iron (III)) [43].

Once detection of the tested compounds was confirmed, we examined the analytical characteristics (linearity $\left(R^{2}\right)$, sensitivity $(S)$, limit of detection - LoD, limit of quantification LoQ) of the developed technique and performed quantification measurements. Figure S1 shows representative calibration curves for the compounds above (zinc acetate, lead acetate, barium acetate and cadmium chloride) in the low $\mathrm{ng} / \mathrm{m}^{3}$ concentration range (below 60 $\left.\mathrm{ng} / \mathrm{m}^{3}\right)$. For the generation of the calibration curves, the effective density of the targeted compounds was used to convert the SMPS data from volume to mass. We observed linear responses for the four metals. Table 1 summarizes our findings for 34 metal-containing compounds. LoD values were based on the main ion observed for each compound; they were calculated based on the $3 \sigma$ criterion (variation of the ion in the blank) and found to be in the low $\mathrm{ng} / \mathrm{m}^{3}$ levels. Integration time was $540 \mathrm{sec}$. LoQ values (again in the low $\mathrm{ng} / \mathrm{m}^{3}$ range) were estimated at 3.3 times the LoD [44]. For the compounds tested (Table 1), the LoD values were between $0.31 \mathrm{ng} / \mathrm{m}^{3}$ and $55.8 \mathrm{ng} / \mathrm{m}^{3}$ with an average of $13.9 \mathrm{ng} / \mathrm{m}^{3}$, whereas the $R^{2}$ values were between 0.9898 and 0.9999 . For the individual metals, the LoD values were 
between $0.05 \mathrm{ng} / \mathrm{m}^{3}$ and $23.72 \mathrm{ng} / \mathrm{m}^{3}$ with an average $4.64 \mathrm{ng} / \mathrm{m}^{3}$. EESI-TOF LoD values (time resolution of $1 \mathrm{sec}$.) were compared with the LoD values of the Xact ${ }^{\circledR} 625 \mathrm{i}$ with time resolution of 15 minutes and presented in Table 1.

Zinc

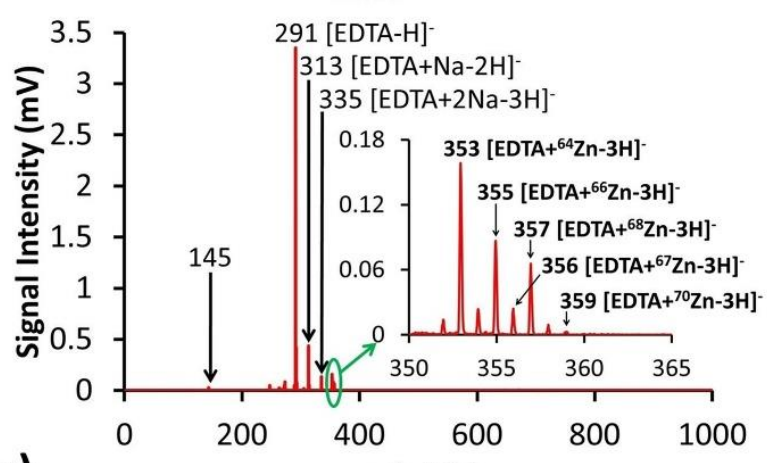

a) $\mathrm{m} / \mathrm{z}$ (Th)
Lead

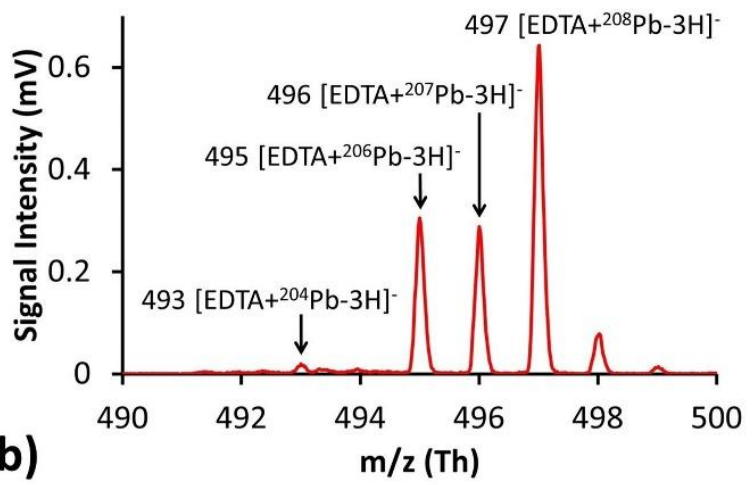

Cadmium

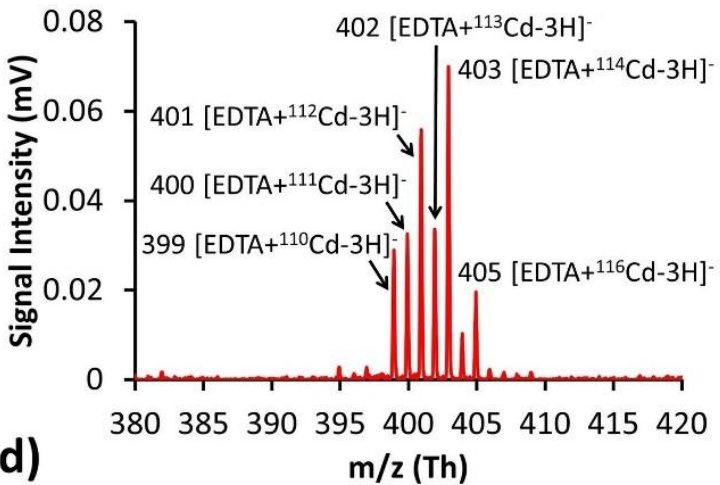

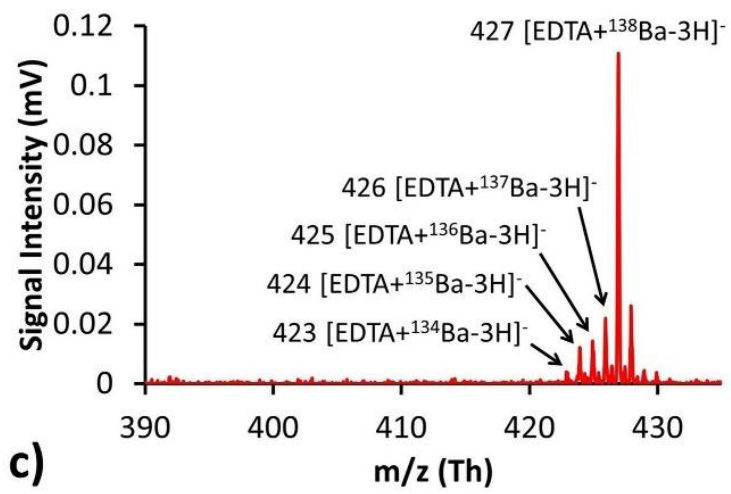

Figure 2. Representative EESI-TOF mass spectra for a) zinc acetate, b) lead acetate, c) barium acetate and d) cadmium chloride obtained from the EESI-TOF-MS.

Table 1: Summary of the analytical characteristics (main ion observed, $R^{2}$ values, LoD and LoQ for the metal-containing compounds in $\mathrm{ng} / \mathrm{m}^{3}$, LoD for each metal) of the EESI-TOF MS during the analysis of water-soluble metal compounds. Comparison with LoD of the Xact ${ }^{\circledR} 625 \mathrm{i}$ (time resolution $15 \mathrm{~min}$ ).

\begin{tabular}{|c|c|c|c|c|c|c|c|}
\hline No & Compound & Main ion observed & $R^{2}$ & $\begin{array}{c}\text { LoD } \\
\left(\mathrm{ng} / \mathrm{m}^{3}\right)\end{array}$ & $\begin{array}{c}\text { LoQ } \\
\left(\mathrm{ng} / \mathrm{m}^{3}\right)\end{array}$ & $\begin{array}{c}\text { EESI-TOF LoD } \\
\text { for the metal } \\
\left(\mathrm{ng} / \mathrm{m}^{3}\right)\end{array}$ & $\begin{array}{c}\text { Xact }^{\circledR} 625 i \text { LoD } \\
\text { for the metal } \\
\left(\mathrm{ng} / \mathrm{m}^{3}\right)\end{array}$ \\
\hline 1 & $\mathrm{LiOH} \cdot \mathrm{H}_{2} \mathrm{O}$ & {$\left[\mathrm{EDTA}+{ }^{7} \mathrm{Li}-2 \mathrm{H}\right]^{-}$} & 0.9985 & 0.3 & 0.9 & 0.05 & N.D. \\
\hline 2 & Lil & 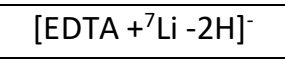 & 0.9998 & 1.9 & 6.7 & 0.10 & N.D. \\
\hline 3 & $\mathrm{CaCl}_{2}$ & {$\left[\mathrm{EDTA}+{ }^{40} \mathrm{Ca}-3 \mathrm{H}\right]^{-}$} & 0.9976 & 2.1 & 6.7 & 0.76 & 7.22 \\
\hline 4 & $\mathrm{MgO}_{4} \mathrm{~S}$ & $\left.\mathrm{EEDTA}^{24} \mathrm{Mg}-3 \mathrm{H}\right]^{-}$ & 0.9985 & 1.1 & 3.3 & 0.22 & N.D. \\
\hline 5 & $\mathrm{CuCl}_{2}$ & {$\left[\mathrm{EDTA}+{ }^{63} \mathrm{Cu}-3 \mathrm{H}\right]^{-}$} & 0.9996 & 2.9 & 9.8 & 1.36 & 2.14 \\
\hline 6 & $\mathrm{CuSO}_{4}$ & ${\left.\text { [EDTA }+{ }^{63} \mathrm{Cu}-3 \mathrm{H}\right]^{-}}^{-}$ & 0.9954 & 3.1 & 9.9 & 1.22 & 2.14 \\
\hline 7 & $\mathrm{CH}_{2} \mathrm{Cu}_{2} \mathrm{O}_{5}$ & {$\left[\mathrm{EDTA}+{ }^{63} \mathrm{Cu}-3 \mathrm{H}\right]^{-}$} & 0.9955 & 5.2 & 17.3 & 1.48 & 2.14 \\
\hline
\end{tabular}




\begin{tabular}{|c|c|c|c|c|c|c|c|}
\hline 8 & $\mathrm{Cu}\left(\mathrm{NO}_{3}\right)_{2} \cdot 2.5 \mathrm{H}_{2} \mathrm{O}$ & {$\left[\text { EDTA }+{ }^{63} \mathrm{Cu}-3 \mathrm{H}\right]^{-}$} & 0.9942 & 5.1 & 17.1 & 1.38 & 2.14 \\
\hline 9 & $\mathrm{AgNO}_{3}$ & {$\left[\mathrm{EDTA}+{ }^{107} \mathrm{Ag}-2 \mathrm{H}\right]^{-}$} & 0.9993 & 14.9 & 49.9 & 9.39 & 34.62 \\
\hline 10 & $\mathrm{CdCO}_{3}$ & {$\left[\mathrm{EDTA}+{ }^{114} \mathrm{Cd}-3 \mathrm{H}\right]^{-}$} & 0.9998 & 4.0 & 13.3 & 2.64 & 45.98 \\
\hline 11 & $\mathrm{CdCl}_{2} \cdot \times \mathrm{H}_{2} \mathrm{O}$ & {$\left[\text { EDTA }+{ }^{114} \mathrm{Cd}-3 \mathrm{H}\right]^{-}$} & 0.9992 & 4.1 & 13.7 & 2.55 & 45.98 \\
\hline 12 & $\mathrm{C}_{4} \mathrm{H}_{6} \mathrm{O}_{4} \mathrm{Zn}$ & {$\left[\mathrm{EDTA}+{ }^{64} \mathrm{Zn}-3 \mathrm{H}\right]^{-}$} & 0.9994 & 8.0 & 26.7 & 2.79 & 1.85 \\
\hline 13 & $\mathrm{ZnSO}_{4} \cdot 7 \mathrm{H}_{2} \mathrm{O}$ & {$\left[\mathrm{EDTA}+{ }^{64} \mathrm{Zn}-3 \mathrm{H}\right]^{-}$} & 0.9990 & 15.6 & 53.3 & 3.47 & 1.85 \\
\hline 14 & $\mathrm{CoCl}_{2} \cdot 6 \mathrm{H}_{2} \mathrm{O}$ & {$\left[\mathrm{EDTA}+{ }^{59} \mathrm{Co}-3 \mathrm{H}\right]^{-}$} & 0.9989 & 7.6 & 25.5 & 1.88 & 2.53 \\
\hline 15 & $\begin{array}{l}\mathrm{Ni}\left(\mathrm{OCOCH}_{3}\right)_{2} \cdot \\
4 \mathrm{H}_{2} \mathrm{O}\end{array}$ & {$\left[\mathrm{EDTA}+{ }^{58} \mathrm{Ni}-3 \mathrm{H}\right]^{-}$} & 0.9997 & 32.9 & 109.9 & 7.67 & 1.81 \\
\hline 16 & $\left(\mathrm{CH}_{3} \mathrm{COO}\right)_{2} \mathrm{Ba}$ & {$\left[\mathrm{EDTA}+{ }^{138} \mathrm{Ba}-3 \mathrm{H}\right]^{-}$} & 0.9987 & 5.00 & 16.7 & 2.70 & 7.56 \\
\hline 17 & Csl & {$\left[\text { EDTA }+{ }^{133} \mathrm{Cs}-2 \mathrm{H}\right]^{-}$} & 0.9976 & 13.0 & 43.3 & 6.65 & N.A. \\
\hline 18 & $\mathrm{HoPO}_{4} \cdot \mathrm{xH}_{2} \mathrm{O}$ & {$\left[{\left.\text { EDTA }+{ }^{165} \mathrm{Ho}-2 \mathrm{H}\right]^{-}}^{-}\right.$} & 0.9964 & 1.9 & 6.7 & 1.21 & N.A. \\
\hline 19 & $\mathrm{FeCl}_{3} \cdot 6 \mathrm{H}_{2} \mathrm{O}$ & {$\left[\mathrm{EDTA}+{ }^{56} \mathrm{Fe}-4 \mathrm{H}\right]^{-}$} & 0.9986 & 2.0 & 6.7 & 0.41 & 6.07 \\
\hline 20 & $\mathrm{FeSO}_{4} \cdot 7 \mathrm{H}_{2} \mathrm{O}$ & {$\left[\mathrm{EDTA}+{ }^{56} \mathrm{Fe}-4 \mathrm{H}\right]^{-}$} & 0.9968 & 9.6 & 33.3 & 1.93 & 6.07 \\
\hline 21 & $\mathrm{La}\left(\mathrm{CH}_{3} \mathrm{CO}_{2}\right)_{3} \cdot \mathrm{xH}_{2} \mathrm{O}$ & 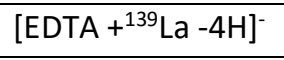 & 0.9991 & 8.1 & 26.6 & 3.56 & N.A. \\
\hline 22 & $\mathrm{Ce}\left(\mathrm{CH}_{3} \mathrm{CO}_{2}\right)_{3} \cdot \mathrm{xH}_{2} \mathrm{O}$ & {$\left[\text { EDTA }+{ }^{140} \mathrm{Ce}-4 \mathrm{H}\right]^{-}$} & 0.9988 & 6.3 & 21.2 & 2.78 & N.A. \\
\hline 23 & $\mathrm{Lu}\left(\mathrm{NO}_{3}\right)_{3} \cdot \mathrm{xH}_{2} \mathrm{O}$ & {$\left[\mathrm{EDTA}^{1}+{ }^{175} \mathrm{Lu}-4 \mathrm{H}\right]^{-}$} & 0.9999 & 25.9 & 86.7 & 12.56 & N.A. \\
\hline 24 & $\mathrm{EuCl}_{3} \cdot 6 \mathrm{H}_{2} \mathrm{O}$ & 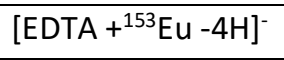 & 0.9972 & 24.0 & 79.9 & 10.02 & N.A. \\
\hline 25 & $\mathrm{GdCl}_{3} \cdot 6 \mathrm{H}_{2} \mathrm{O}$ & {$\left[\mathrm{EDTA}+{ }^{158} \mathrm{Gd}-4 \mathrm{H}\right]^{-}$} & 0.9979 & 55.8 & 186.5 & 23.72 & N.A. \\
\hline 26 & $\mathrm{DyCl}_{3} \cdot 6\left(\mathrm{H}_{2} \mathrm{O}\right)$ & 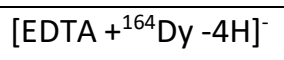 & 0.9989 & 38.9 & 129.8 & 16.92 & N.A. \\
\hline 27 & $\begin{array}{l}\mathrm{Pb}\left(\mathrm{CH}_{3} \mathrm{CO}_{2}\right)_{2} . \\
3 \mathrm{H}_{2} \mathrm{O}\end{array}$ & $\left.\mathrm{EEDTA}^{2}{ }^{208} \mathrm{~Pb}-3 \mathrm{H}\right]^{-}$ & 0.9998 & 7.6 & 25.4 & 4.17 & 1.75 \\
\hline 28 & $\operatorname{Pr}\left(\mathrm{NO}_{3}\right)_{3} \cdot 6 \mathrm{H}_{2} \mathrm{O}$ & 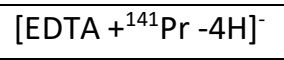 & 0.9972 & 16.1 & 53.2 & 5.22 & N.A. \\
\hline 29 & $\mathrm{Nd}\left(\mathrm{NO}_{3}\right)_{3} \cdot 6 \mathrm{H}_{2} \mathrm{O}$ & {$\left[\mathrm{EDTA}+{ }^{142} \mathrm{Nd}-4 \mathrm{H}\right]^{-}$} & 0.9981 & 19.8 & 66.7 & 6.41 & N.A. \\
\hline 30 & $\mathrm{Tm}\left(\mathrm{NO}_{3}\right)_{3} \cdot 5 \mathrm{H}_{2} \mathrm{O}$ & {$\left[\mathrm{EDTA}+{ }^{169} \mathrm{Tm}-4 \mathrm{H}\right]^{-}$} & 0.9990 & 20.0 & 66.7 & 7.59 & N.A. \\
\hline 31 & $\mathrm{Yb}\left(\mathrm{NO}_{3}\right)_{3} \cdot 5 \mathrm{H}_{2} \mathrm{O}$ & 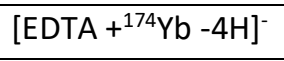 & 0.9963 & 9.1 & 29.9 & 3.53 & N.A. \\
\hline 32 & $\mathrm{~Tb}\left(\mathrm{NO}_{3}\right)_{3} \cdot 5 \mathrm{H}_{2} \mathrm{O}$ & {$\left[\mathrm{EDTA}+{ }^{159} \mathrm{~Tb}-4 \mathrm{H}\right]^{-}$} & 0.9986 & 18.7 & 63.3 & 6.56 & N.A. \\
\hline 33 & $\mathrm{Er}_{2}\left(\mathrm{CO}_{3}\right)_{3} \cdot \mathrm{xH}_{2} \mathrm{O}$ & [EDTA $\left.+{ }^{166} \mathrm{Er}-4 \mathrm{H}\right]^{-}$ & 0.9990 & 14.5 & 49.9 & 4.68 & N.A. \\
\hline 34 & $\left(\mathrm{CH}_{3} \mathrm{CO}_{2}\right) 7 \mathrm{Cr}_{3}(\mathrm{OH})_{2}$ & {$\left[\mathrm{EDTA}+{ }^{52} \mathrm{Cr}-4 \mathrm{H}\right]^{-}$} & 0.9995 & 1.0 & 3.3 & 0.09 & 2.31 \\
\hline
\end{tabular}

N.D.: Not detectable

N.A.: Not available information

\subsection{Mixture experiments}

To investigate the extension of analyte-analyte interactions on the EESI-TOF detection, we performed a series of experiments assessing the instrument response to internal and external mixtures of metal salts. The value of these experiments is to show how easy the EESI-TOF can resolve the composition of a complex mixture of metal-containing compounds and to provide information on the retention time. For the first sample mixing approach (internally mixed particles), a $1000 \mathrm{ppb}$ sample solution of lead acetate trihydrate, cadmium chloride hydrate, zinc acetate, cerium (III) acetate hydrate and barium acetate was prepared using ultrapure water. The sample was then diluted 5 times by a factor of 2 each time (resulting in 
concentrations of $1000,500,250,125,62.5,31.25 \mathrm{ppb})$. The samples were then transferred to the 2DX autosampler and nebulized using the apex $Q$ Desolvating nebulizer from the lowest concentration to the highest. A representative mass spectrum can be found in Figure 3a. The individual metals of $\mathrm{Pb}(\mathrm{m} / \mathrm{z} 497), \mathrm{Cd}(\mathrm{m} / \mathrm{z} 403), \mathrm{Zn}(\mathrm{m} / \mathrm{z} 353), \mathrm{Ce}(\mathrm{m} / \mathrm{z} 423)$ and $\mathrm{Ba}(\mathrm{m} / \mathrm{z} 427)$ are detectable as complexes with EDTA ([EDTA $\left.+{ }^{208} \mathrm{~Pb}-3 \mathrm{H}\right]^{-}$, [EDTA $\left.+{ }^{114} \mathrm{Cd}-3 \mathrm{H}\right]^{-}$, [EDTA $+{ }^{64} \mathrm{Zn}-$ $3 \mathrm{H}]^{-}$, [EDTA $\left.+{ }^{140} \mathrm{Ce}-4 \mathrm{H}\right]$ 'and [EDTA $\left.+{ }^{138} \mathrm{Ba}-3 \mathrm{H}\right]^{-}$) and their isotopes are clearly distinguished.

The second sample mixing approach was done as follows: a constant aerosol flow of lithium hydroxide monohydrate (generated by a manually built-in-house nebulizer) was mixed with a dynamic aerosol flow (produced by the 2DX autosampler and the apex $Q$ Desolvating nebulizer) of a mixture of lead acetate trihydrate, cadmium chloride hydrate and cerium (III) acetate hydrate (Figure $3 \mathrm{~b}$ ). The sample solution was $500 \mathrm{ppb}$ prepared in water, and increasing atmospheric concentrations were created by varying the sample air flow rate. The two aerosol flows were mixed within a $6.35 \mathrm{~mm}$ standard Swagelok T-piece union and the combined flow was passing through the dryer to the core-sampling dilution chamber prior to the introduction in the EESI source and the TOF mass analyzer. The average rise time (time required for the signal to reach its maximum intensity) for the compounds tested was in the range between 4 and 7 seconds whereas the washout time (time needed for the signal to drop at the $90 \%$ of the maximum signal intensity) was $4 \mathrm{sec}$ (Figure $3 \mathrm{~b}$ ). In total about $35 \mathrm{sec}$ were required for the signal intensities to return to the background level.
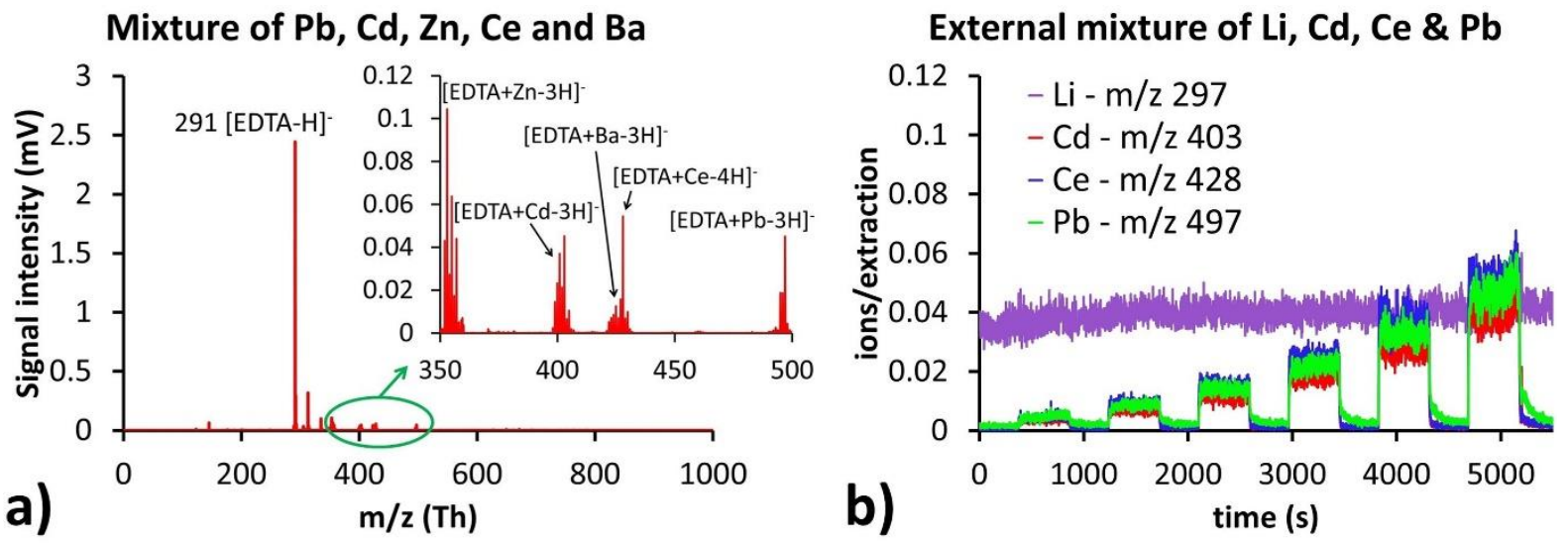

Figure 3. a) Experimental mass spectrum of a mixture of zinc acetate, cadmium chloride hydrate, zinc acetate, cerium (III) acetate tetrahydrate and barium acetate obtained with the EESI-TOF-MS, b) time-series of an external mixture of lithium hydroxide monohydrate and lead acetate trihydrate, cadmium chloride hydrate and cerium (III) acetate hydrate. 
To examine the response and the robustness of the EESI source concerning matrix effects and/or ion suppression processes (a common issue in infusion electrospray ionization), we tested a set of internally mixed aerosols of varying composition. Specifically, we prepared an aqueous solution of lead acetate trihydrate, cadmium chloride hydrate, zinc acetate, cerium (III) acetate hydrate at $200 \mathrm{ppb}$ each. This solution was then divided into 5 equal parts that were each doped with the same volume of a solution of lithium hydroxide monohydrate with increasing concentration (100 ppb, 200 ppb, 700 ppb, 1000 ppb and 2000 ppb) and then nebulized. Figure 4 shows that the EESI-TOF detection efficiency of a given metal is unaffected by changes in analyte composition.

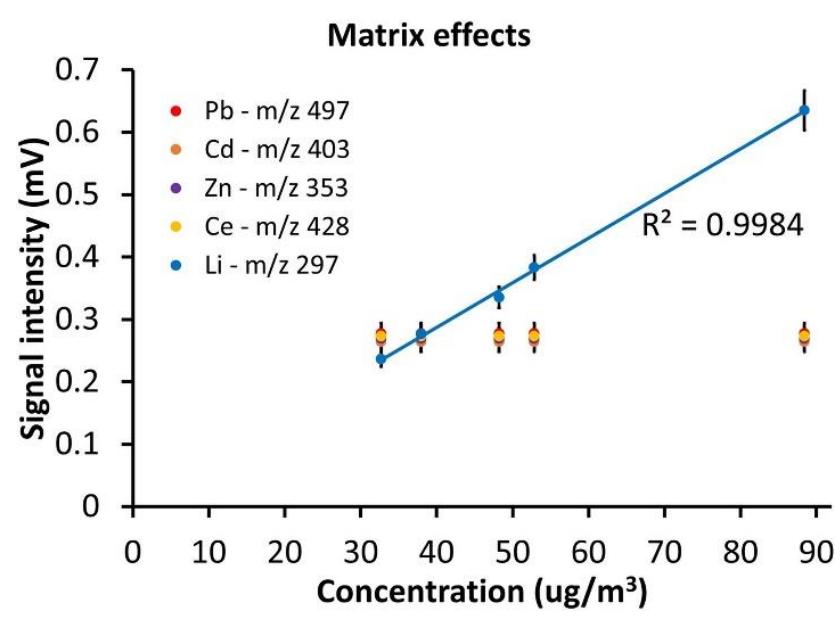

Figure 4. Testing of matrix effects. Signal intensity for a mixture of $\mathrm{Pb}, \mathrm{Cd}, \mathrm{Zn}$ and $\mathrm{Ce}$ at constant concentration mixed with $\mathrm{Li}$ at increasing concentration.

\subsection{Water vapor dependence}

A requirement for any detector in the ambient atmosphere is its stability against varying meteorological parameters. Changing sample conditions may affect the whole detection technique (e.g. evaporation, electrospray, ionization pattern). Therefore, we investigated the effect of water vapor on the EESI-TOF-MS signal. Water vapor can possibly affect sensitivity either by competing with the analytes or by absorbing energy from them [30]. In addition, it may impact the stability of the electrospray ions and thus affect the stability of any online measurement with qualitative and semi-quantitative information. Samples of lead acetate and calcium chloride were prepared and nebulized as described above. The selection of lead and calcium was done based on their high environmental interest. The generated aerosol flow 
passed through a silica gel dryer resulting in an aerosol flow with approximately $23 \%$ relative humidity $(\mathrm{RH})$ at room temperature. This flow was then diluted in a core-sampling chamber (as described in Section 2.4) with dry synthetic air, resulting in a $10 \% \mathrm{RH}$ sample flow. A second, wet flow was generated by a dry synthetic airflow passing via a water bubbler kept at room conditions. This flow was mixed with the former prior to the core-sampling chamber and by adjusting the ratio between the two flows, we generated a sample flow with the desired $\mathrm{RH}$. The produced flow was then fed through the multichannel denuder to the EESI source. Figure 5 shows the high stability of the signal of the [EDTA $+{ }^{208} \mathrm{~Pb}-3 \mathrm{H}$ ] at $\mathrm{m} / \mathrm{z} 497$ and [EDTA $\left.+{ }^{40} \mathrm{Ca}-3 \mathrm{H}\right]^{-}$at $\mathrm{m} / \mathrm{z} 329$ over the full range of $\mathrm{RH}$ varying from $10 \%$ up to $100 \%$. The relative EDTA-water cluster signal, i.e., [EDTA-H2O]/[ [EDTA-H]', generated in the spray was also monitored to be stable throughout the whole experiment. This indicates the strength and the stability of the formed Taylor cone generated by the EESI capillary at varying water vapor concentrations.

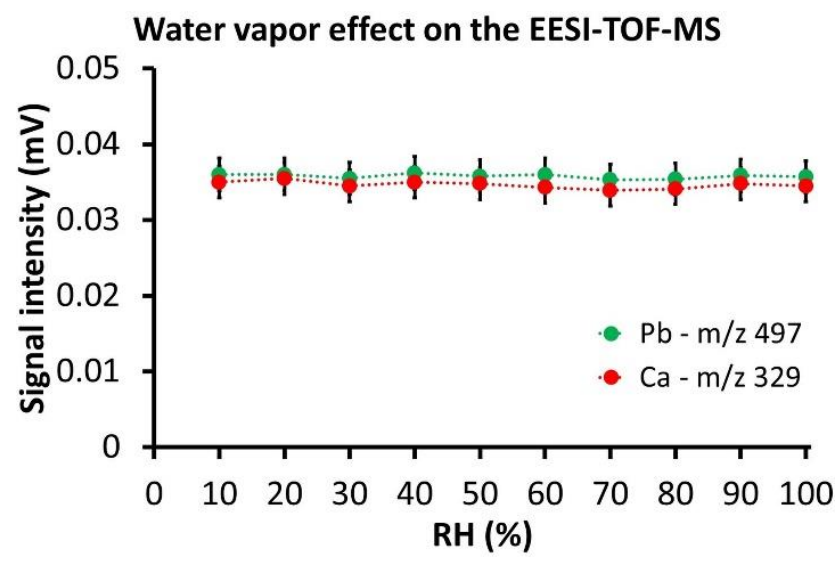

Figure 5. Effect of water vapor on the EESI-TOF MS signal for lead acetate and calcium chloride.

\subsection{Benchmark testing against ICP-MS}

The EESI-TOF-MS measurement data were benchmarked against ICP-MS, which is a standard offline method for the trace and ultra-trace analysis of liquid samples. In this study, an ICPMS 7700x from Agilent was used. About $25 \mathrm{mg}$ of each metal compound (the same used for the EESI-TOF-MS analysis) were diluted in few milliliters of high-purity concentrated $\mathrm{HNO}_{3}$ (65\%). Each dissolved material was then diluted in seven steps in $1 \% \mathrm{HNO}_{3}$ (prepared with MilliQ water and the same $\mathrm{HNO}_{3}$ used for the digestion). The parameters (Table $\mathrm{S} 3$ in the $\mathrm{SI}$ ) 
of the ICP-MS instrument were optimized using 1-ppb multi-standard solutions, containing $\mathrm{Mg}$, Co, $\mathrm{Y}, \mathrm{Ce}$, and $\mathrm{TI}$, to achieve the highest sensitivity and the lowest oxidation ratio $\left(\mathrm{CeO}^{+} / \mathrm{Ce}^{+}<1 \%\right)$.

The four most diluted samples with concentrations ranging from 0 to $100 \mathrm{ppb}(\mathrm{ng} / \mathrm{mL})$ of each metal compound were measured using the isotopes reported in the Table S3. Table S4 (in the SI) summarizes the analytical characteristics (linear regression within the examined concentration area $-R^{2}$, sensitivity - $S$ (in $\mathrm{cps} / \mathrm{ppb}$ ), background equivalent concentration BEC, LoD and LoQ) of the ICP-MS system for the compounds tested. The LoD of the metal compounds were calculated based on the $3 \sigma$ criterion ( $L O D=3 \sigma / S$ ). ICP-MS is an elementspecific method and thus the LoD of different compounds containing the same metal is similar. From the LoD of each metal, the corresponding LoD of the metal-containing compound was calculated. For the concentration area tested, the $R^{2}$ of the examined compounds was between 0.9993 and 1 , whereas the LoD obtained were in the low $\mathrm{ng} / \mathrm{m}^{3}$.

The comparison of the EESI-TOF-MS and ICP-MS results involves some steps, because the latter is an offline method where the analyte needs to be in liquid form. For an aerosol, however, the analyte is first sampled, for example on a filter (in particulate form), then dissolved in an acidic medium prior to analysis. We assume that we need a volume $\mathrm{V}_{\mathrm{g}}$ to sample an amount $\mathrm{m}$ of a metal on a filter which is then dissolved in a volume of a liquid $\mathrm{V}_{\text {I. }}$. Then the ratio of the two volumes $\left(\mathrm{V}_{\mathrm{g}} / \mathrm{V}_{\mathrm{l}}\right)$ can be used to convert the ICP-MS data from $\mathrm{ng} / \mathrm{mL}$ to $\mathrm{ng} / \mathrm{m}^{3}$, thus, the $\operatorname{LoD}\left(\mathrm{ng} / \mathrm{m}^{3}\right)=\operatorname{LoD}(\mathrm{ng} / \mathrm{mL}) *\left(\mathrm{~V}_{\mathrm{I}} / \mathrm{V}_{\mathrm{g}}\right)$. In our case, $\mathrm{V}_{\mathrm{g}}$ was assumed to be 10 $\mathrm{L}$ and $\mathrm{V}_{\mathrm{I}}$ equal to $0.1 \mathrm{~L}$.

Table 2 presents a comparison between the LoD that we obtained for 12 metal-containing compounds using the developed EESI-TOF-MS approach and the ICP-MS system. As it can be seen, the LoD values for the EESI-TOF-MS are comparable to or better than for ICP-MS. In the case of Fe, ICP-MS has high LoD due to argon interferences, whereas the ICP-MS presents better linearity for the concentration area tested.

Table 2: Comparison of the EESI and ICP-MS performance.

\begin{tabular}{|l|c|c|}
\hline Compound & EESI-TOF-MS, LoD $\left(\mathbf{n g} / \mathrm{m}^{\mathbf{3}}\right)$ & ICP-MS, LoD $\left(\mathbf{n g} / \mathrm{m}^{\mathbf{3}}\right)$ \\
\hline Lead acetate trihydrate & 7.6 & 0.5 \\
\hline
\end{tabular}




\begin{tabular}{|l|c|c|} 
Zinc acetate anhydrous & 8.0 & 508.8 \\
\hline Cadmium chloride hydrate & 6.1 & 5.0 \\
\hline Copper (II) sulfate & 3.1 & 11.8 \\
\hline Cobalt (II) chloride hexahydrate & 7.6 & 0.3 \\
\hline Iron (III) chloride hexahydrate & 2.0 & 866.6 \\
\hline Iron (II) sulfate heptahydrate & 9.6 & 906.8 \\
\hline Cadmium carbonate & 4.0 & 4.4 \\
\hline Copper (II) carbonate hydroxide & 5.0 & 7.7 \\
\hline Magnesium sulfate anhydrous & 1.1 & 21.6 \\
\hline Lithium iodide & 1.9 & 23.7 \\
\hline Cerium (III) acetate hydrate & 6.3 & 3.7 \\
\hline
\end{tabular}

\subsection{Field testing}

Proof-of-concept measurements of metals in atmospheric aerosol were conducted during January 2019 in New Delhi, India. The EESI-TOF-MS was deployed at the Centre for Atmospheric Sciences in the Indian Institute of Technology Delhi (IITD). The surrounding area is an urban environment consisting of the IITD campus, small businesses (e.g. restaurants, auto repair shops, metal processing small units), and highways with high traffic. Ambient air was continuously sampled through a PM 2.5 inlet into a $200 \mathrm{~mm}$ (10 mm ID) SS sample transfer line and was introduced into the EESI-TOF-MS. The sample transfer line was split in two sublines: a) a particle flow line and b) a high-efficiency particulate air filter line. Switching between the two lines was done using a high precision automated servo valve (Hitec HS$755 \mathrm{MG})$. Sampling alternated between $240 \mathrm{sec}$ of particle flow and $180 \mathrm{sec}$ of filter/blank measurements with mass spectra recorded at $5 \mathrm{sec}$ time resolution. Time series of selected metal compounds $(\mathrm{Fe}, \mathrm{Cu}, \mathrm{Pb})$, as well as primary ions from the spray, recorded on 30 January 2019 between 1 pm and 7 pm local time are shown in Figure 6. The spray ions are shown in Figure $6 a$ and are quite stable during the measurement period except when the valve is switching between sample and filter positions, which causes a transient pressure change that temporarily disrupts the spray. The insert in Figure 6a shows the stability of the electrospray ions within a time window of 1 hour. The percent difference in signal of each of the three spray ions between the particle and filter lines is $3.1 \%$ for the $m / z 291,3.6 \%$ for the $m / z 313$ and $3.2 \%$ for the $m / z 335$. Figure $6 \mathrm{~b}$ shows the time series of $\mathrm{Fe}(\mathrm{m} / \mathrm{z} 344)$ and $\mathrm{Cu}(\mathrm{m} / \mathrm{z} 352)$, whereas Figure $6 c$ shows the time series of two isotopes of $\mathrm{Pb}(\mathrm{m} / \mathrm{z} 497$ and 496). Three events (lasting 30, 40 and 40 minutes) were observed and monitored in real time during this period, demonstrating the suitability of the method for atmospheric sampling of highly 
transient signals. In contrast, other techniques (online - Xact ${ }^{\circledR} 625 \mathrm{i}$ or offline - ICP-MS) would not be able to catch so clearly and monitor these events because of sampling effects (e.g. slow sampling times and sample collection of filters).

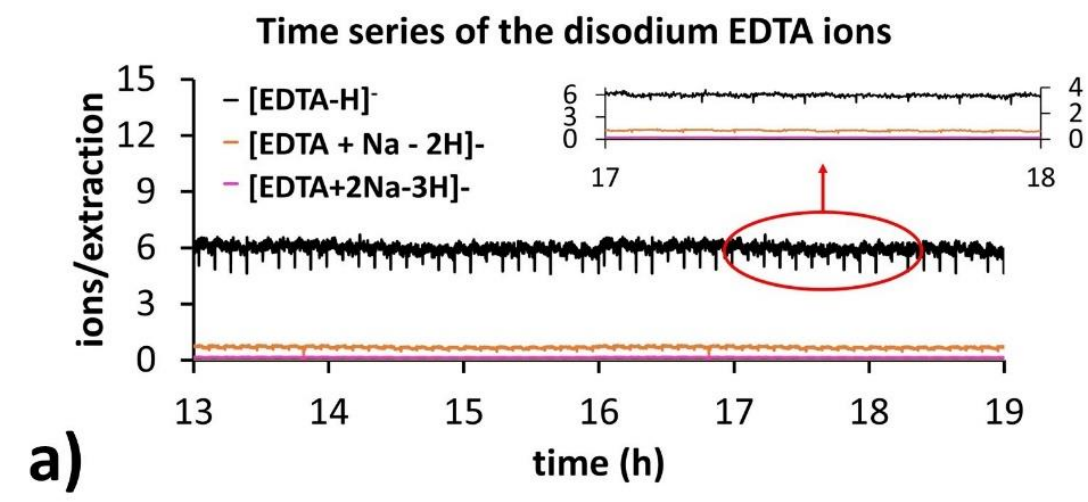

Time series of Fe \& Cu emissions in New Delhi

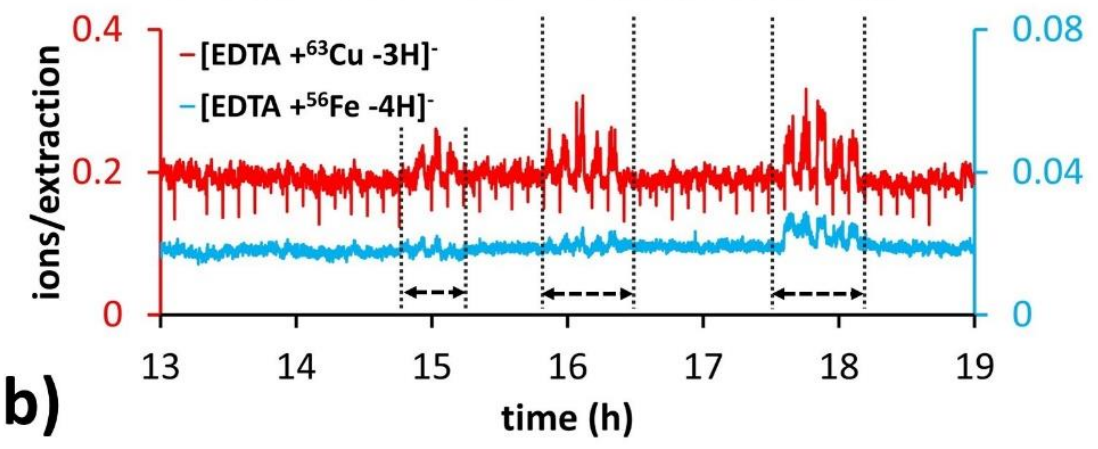

Time series of $\mathrm{Pb}$ emissions in New Delhi

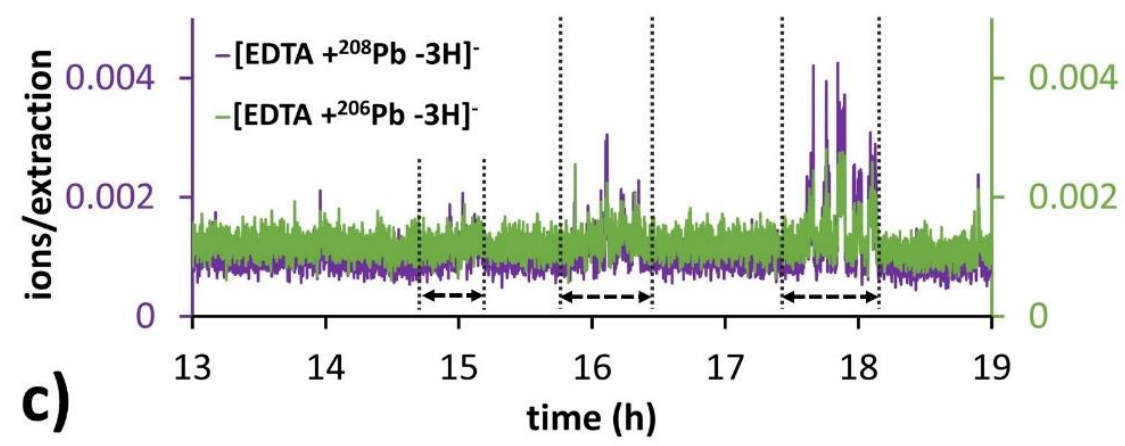

Figure 6. Time series of target metal emissions detected with the EESI-TOF-MS in ambient air of New Delhi, India. Time series of a) the primary ions 291, 313 and 335 of EDTA, b) Fe $(\mathrm{m} / \mathrm{z}$ 344) and $\mathrm{Cu}(\mathrm{m} / \mathrm{z} 352)$ concentrations and c) $\mathrm{Pb}(\mathrm{m} / \mathrm{z} 497$ and 496$)$ signal intensities over a period of $6 \mathrm{~h}$. Time resolution was $5 \mathrm{sec}$. The double arrows indicate three events observed.

\section{CONCLUSIONS}


We present a new technique for online, highly time-resolved and accurate detection of watersoluble metals in aerosol particles using an extractive electrospray ionization (EESI) source coupled to a portable high-resolution TOF-MS. Metals are detected in the EESI negative ionization mode using disodium EDTA dehydrate as a strong and universal metal chelation agent. Experiments were conducted for 34 different metal compounds including 27 different metals of environmental interest. The results obtained showed very good linearity $\left(R^{2}\right.$ up to 0.999) within the examined concentration range, fast response times $(1 \mathrm{~Hz})$, low LoD (low $\mathrm{ng} / \mathrm{m}^{3}$ ) and LoQ values. We also examined the behaviour of the EESI source under complex dynamic cases obtaining high repeatability and stability of our approach. Effects arising from matrix and water vapour were investigated. Benchmark testing against a commercial ICP-MS system was also performed, giving outstanding results. Proof-of-concept field measurements were conducted on atmospheric aerosols in the urban environment of New Delhi, India and positive results were obtained allowing further exploitation.

Compared to existing technologies for metal detection, the portable EESI-TOF-MS provides high sensitivity (low detection limits - few $\mathrm{ng} / \mathrm{m}^{3}$ ), online chemical analysis (time resolution of $1 \mathrm{~Hz}$ ), high mass to charge resolution (up to $14000 \mathrm{Th} / \mathrm{Th}$ ), high reliability (elimination of artifacts - no sample collection, transfer and storage contamination risks), and robustness in harsh environments. The EESI source does not suffer from thermal treatment artifacts and thus particulate metal samples do not experience thermal fragmentation or thermal oxidation, and memory effects or cross sampling contamination artifacts are not present.

The use of a portable or field deployable chemical sensor with the above characteristics, addressing all the requirements raised during harsh environment operations (e.g. extreme $\mathrm{RH}$ and/or temperature environment such as a desert or an Arctic ice island, high PM mass concentration, etc.) for harmful or toxic substances detection, is of great interest and attractive to environmental investigators for real-time decision-making at the point of analysis. The EESI-TOF-MS as a new tool will allow a better understanding of the fundamental processes of metals' emission and their evolution in the environment or industry.

\section{ACKNOWLEDGEMENTS}

This project has received funding from the European Union's Horizon 2020 research and innovation program under the Marie Skłodowska-Curie grant agreement No 701647, the Division of Energy and Environment Research at PSI (Inter-Laboratory Postdoc program) and 
by the Swiss National Science Foundation, grant agreement BSSGI0_155846 and

200020_172602. The authors gratefully acknowledge Dr. Josef Dommen, Dr. Imad El Haddad,

Dr. David Bell, Dr. Martin Gysel, Dr. Julia Schmale, Dr. Markus Furger, Varun Kumar, Pragati

Rai and Yandong Tong from the Laboratory of Atmospheric Chemistry, PSI for their assistance and support of this work. Special thanks are due to TOFWERK AG, Switzerland for their technical support, to Prof. Dr S. N. Tripathi from the Department of Civil Engineering (Centre for Environmental Science and Engineering Indian Institute of Technology Kanpur, India) and to Dr Dilip Ganguly from the Centre for Atmospheric Sciences at the Indian Institute of Technology in Delhi, for hosting our instrumentation during the field trials and facilitating our experimental work in India.

\section{REFERENCES}

[1] WHO: Review of evidence on health aspects of air pollution - REVIHAAP project, World Health Organization, 2013.

[2] Winkel, L. H. E.; Johnson, C. A.; Lenz, M.; Grundl, T.; Leupin, O. X.; Amini M.; Charlet, L. Environmental selenium research: from microscopic processes to global understanding Environ. Sci. Technol. 2012, DOI: 10.1021/es203434d.

[3] Dockery, D. W.; Pope, C. A. Accure respiratory effects of particulate air pollution Annu. Rev. Public Health 1994, DOI: 10.1146/annurev.pu.15.050194.000543.

[4] Miller, F. J.; Gardner, D. E.; Graham, J. A.; Lee, R. E.; Wilson, W. E.; Bachmann J. D. Size considerations for establishing a standard for inhalable particles Journal of the Air Pollution Control Association 1979, DOI:10.1080/00022470.1979.10470831.

[5] Kelly, F. J.; Fussell, J. C. Size, source and chemical composition as determinants of toxicity attributable to ambient particulate matter Atmospheric Environment 2012, DOI:10.1016/j.atmosenv.2012.06.039 (2012).

[6] Bartholomew, C. H. Mechanisms of catalyst deactivation, Appl. Catal. 2001, DOI: 10.1016/S0926860X(00)00843-7.

[7] Andersson, J.; Antonsson, M.; Eurenius, L.; Olsson, E.; Skoglundh, M. Deactivation of diesel oxidation catalysis: vehicle- and synthetic aging correlations, Applied Catalysis B: Environmental 2007, DOI: 10.1016/j.apcatb.2006.10.011, 2007.

[8] Manke, A.; Wang, L.; Rojanasakul, Y. Mechanisms of nanoparticle-induced oxidative stress and toxicity. Biomed. Res. Int. 2013, DOI:10.1155/2013/942916.

[9] Daellenbach, K. R.; Stefenelli, G.; Bozzetti, C.; Vlachou, A.; Fermo, P.; Gonzalez, R.; Piazzalunga, A.; Colombi, C.; Canonaco, F.; Hueglin, C.; Kaspar-Giebl, A.; Jaffrezo, J.-L.; Bianchi, F.; Slowik, J. G.; Baltensperger, U.; El Haddad, I.; Prévôt, A. S. H. Long-term chemical analysis and organic aerosol source apportionment at nine sites in Central Europe: source identification and uncertainty assessment, Atmos. Chem. Phys. 2017, DOI: 10.5194/acp-17-13265-2017.

[10] Canagaratna, M. R.; Jayne, J. T.; Jimenez, J. L.; Allan, J. D.; Alfarra, M. R.; Zhang, Q.; Onasch, T. B.; Drewnick, F.; Coe, H.; Middlebrook, A.; Delia, A.; Williams, L. R; Trimborn, A. M.; Northway, M. J.; DeCarlo, P. F.; Kolb, C. E.; Davidovits, P.; Worsnop, D. R. Chemical and microphysical characterization of ambient aerosols with the Aerodyne aerosol mass spectrometer, Mass Spectrometry Reviews, 2007, DOI: 10.1002/mas.20115.

[11] Goldstein, A. H.; Galbally, I. E. Known and unexplored organic constituents in the earth's atmosphere, Environmental Science \& Technology, 2007, DOI:10.1021/Es072476p.

[12] Horan, A. J.; Gao, Y.; Hall, W. A.; Johnston, M. V. Online characterization of particles and gases with an ambient electrospray ionization source, Anal. Chem. 2012, DOI: 10.1021/ac302024y.

[13] lyer, S.; Lopez-Hilfiker, F. D.; Lee, B. H.; Thornton, J. A.; Kurtén, T. Modeling the detection of organic and inorganic compounds using iodide-based chemical ionization, J. Phys. Chem. A 2016, DOI: 10.1021/acs.jpca.5b09837. 
[14] Jimenez, J. L.; Canagaratna, M. R.; Donahue, N. M.; Prevot, A. S.; Zhang, Q.; Kroll, J. H.; DeCarlo, P. F.; Allan, J. D.; Coe, H.; Ng, N. L.; Aiken, A. C.; Docherty, K. S.; Ulbrich, I. M.; Grieshop, A. P.; Robinson, A. L.; Duplissy, J.; Smith, J. D.; Wilson, K. R.; Lanz, V. A.; Hueglin, C.; Sun, Y. L.; Tian, J.; Laaksonen, A.; Raatikainen, T.; Rautiainen, J.; Vaattovaara, P.; Ehn, M.; Kulmala, M.; Tomlinson, J. M.; Collins, D. R.; Cubison, M. J.; Dunlea, E. J.; Huffman, J. A.; Onasch, T. B.; Alfarra, M. R.; Williams, P. I.; Bower, K.; Kondo, Y.; Schneider, J.; Drewnick, F.; Borrmann, S.; Weimer, S.; Demerjian, K.; Salcedo, D.; Cottrell, L.; Griffin, R.; Takami, A.; Miyoshi, T.; Hatakeyama, S.; Shimono, A.; Sun, J. Y.; Zhang, Y. M.; Dzepina, K.; Kimmel, J. R.; Sueper, D.; Jayne, J. T.; Herndon, S. C.; Trimborn, A. M.; Williams, L. R.; Wood, E. C.; Middlebrook, A. M.; Kolb, C. E.; Baltensperger, U.; Worsnop, D. R. Evolution of organic aerosols in the atmosphere, Science, 2009, DOI:10.1126/science.1180353.

[15] Salcedo, D.; Laskin, A.; Shutthanandan, V.; Jimenez, J. L. Feasibility of the detection of trace elements in particulate matter using online high-resolution aerosol mass spectrometry, Aerosol Science and Technology 2012, DOI: 10.1080/02786826.2012.701354.

[16] Salcedo, D.; Onasch, T. B.; Williams, L. R.; Foy, B.; Cubison, M. J.; Worsnop, D. R.; Molina, L. T.; Jimenez, J. L. Determination of particulate lead using aerosol mass spectrometry: MILAGRO/MCMA-2006 observations, Atmospheric Chemistry and Physics 2010, DOI: 10.5194/acp-10-5371-2010.

[17] Moffet, R. C.; Desyaterik, Y.; Hopkins, R. J.; Tavanski, A. V.; Gilles, M. K.; Wang, Y.; Shutthanandan, V.; Molina, L. T.; Gonzalez, R.; Johnson, K. S.; Mugica, V.; Molina, M. J.; Laskin, A.; Prather, K. A. Characterization of aerosols containing $\mathrm{Zn}, \mathrm{Pb}$ and $\mathrm{Cl}$ from an industrial region of Mexico city, Environmental Science and Technology 2008, DOI: 10.1021/es7030483.

[18] Ishizaka, T.; Tohno, S.; Mab, C. -J.; Takaoka, M.; Nishiyama, F.; Yamamoto, K. Reactivity between $\mathrm{PbSO}_{4}$ and $\mathrm{CaCO}_{3}$ particles relevant to the modification of mineral particles and chemical forms of $\mathrm{Pb}$ in particles samples at two remote sites during an Asian dust event, Atmospheric Environment 2009, DOI: 10.1016/j.atmosenv.2009.02.041.

[19] Wellinger, M.; Wochele, J.; Biollaz, S. M. A.; Ludwig, C. Online elemental analysis of process gases with ICPOES: a case study on waste wood combustion, Waste Management 2012, DOI: 10.1016/j.wasman.2012.05.015.

[20] Edinger, P.; Tarik, M.; Hess, A.; Testino, A.; Ludwig, C. Online detection of selenium and its retention in reducing gasification atmosphere, Energy Fuels 2016, DOI: 10.1021/acs.energyfuels.5b02608.

[21] Visser, S.; Slowik, J. G.; Furger, M.; Zotter, P.; Bukowiecki, N.; Dressler, R.; Flechsig, U.; Appel, K.; Green, D. C.; Tremper, A. H.; Young, D. E.; Williams, P. I.; Allan, J. D.; Herndon, S. C.; Williams, L. R.; Mohr, C.; Xu, L.; Ng, N. L.; Detournay, A.; Barlow, J. F.; Halios, C. H.; Fleming, Z. L.; Baltensperger, U.; Prévôt, A. S. H. Kerb and urban increment of highly time-resolved trace elements in PM10, PM2.5 and PM1.0 winter aerosol in London during ClearfLo 2012, Atmos. Chem. Phys. 2015, DOI: 10.5194/acp-15-2367-2015.

[22] Furger, M.; Minguillón, M. C.; Yadav, V.; Slowik, J. G.; Hüglin, C.; Fröhlich, R.; Petterson, K.; Baltensperger, U.; Prévôt, A. S. H. Elemental composition of ambient aerosols measured with high temporal resolution using an online XRF spectrometer, Atmos. Meas. Tech. 2017, DOI: 10.5194/amt-10-2061-2017.

[23] Cisper, M. E.; Hemberger, P. H. Organometallic analysis by membrane introduction mass spectrometry, Rapid Communications in Mass Spectrometry 1997, DOI:10.1002/(SICI)10970231(19970830)11:13<1454::AID-RCM27>3.0.CO;2-X.

[24] Cooper Environmental Services LLC, http://cooperenvironmental.com/, last accessed 26/08/2019.

[25] Cooper, J. A.; Petterson, K.; Geiger, A.; Siemers, A.; Rupprecht, B. Guide for developing a multi-metals, fenceline monitoring plan for fugitive emissions using X-ray based monitors, Cooper Environmental Services, Portland, Oregon 2010.

[26] Furger, M.; Minguillon, M. C.; Yadav, V.; Slowik, J. G., Hüglin, C.; Fröhlich, R.; Petterson, K.; Baltensperger, U.; Prévôt, A. S. H. Elemental composition of ambient aerosols measured with high temporal resolution using an online XRF spectrometer. Atmospheric Measurement Techniques 2017, DOI: 10.5194/amt-102061-2017.

[27] Tremper, A. H.; Font, A.; Priestman, M.; Hamad, S. H.; Chung, T. C.; Pribadi, A.; Brown, R. J. C.; Goddard, S. L. ; Grassineau, N.; Petterson, K.; Kelly, F.; Green, D. C. Field and laboratory evaluation of a high time resolution $\mathrm{x}$-ray fluorescence instrument for determining the elemental composition of ambient aerosols. Atmospheric Measurement Techniques 2018, DOI:10.5194/amt-11-3541-2018.

[28] Onasch, T. B.; Trimborn, A.; Fortner, E. C.; Jayne J. T.; Kok, G. L.; Williams, L. R., Davidovits, P.; Worsnop, D. R. Soot particle aerosol mass spectrometer: development, validation, and initial application, Aerosol Science and Technology 2012, DOI: 10.1080/02786826.2012.663948.

[29] Cooks, R. G.; Ouyang, Z.; Takats, Z.; Wiseman, J. M. Detection technologies. Ambient mass spectrometry, Science 2006, DOI: 10.1126/science.1119426. 
[30] Lopez-Hilfiker, F. D.; Pospisilova, V.; Huang, W.; Kalberer, M.; Mohr, C.; Stefenelli, G.; Thornton, J. A.; Baltensperger, U.; Prevot, A. S. H.; Slowik, J. G. An extractive electrospray ionization time-of-flight mass spectrometer (EESI-TOF) for online measurement of atmospheric aerosol particles, Atmospheric Measurements and Technology 2019, DOI: 10.5194/amt-2019-45.

[31] Doezema, L. A.; Longin, T.; Cody, W.; Perraud, V.; Dawson, M. L.; Ezell, M. J.; Greaves, J.; Johnson, K. R.; Finlayson-Pitts, B. J. Analysis of secondary organic aerosols in air using extractive electrospray ionization mass spectrometry (EESI-MS), RSC Advances 2012, DOI: 10.1039/C2RA00961G.

[32] Gallimore, P. J.; Kalberer, M.; Characterizing an extractive electrospray ionization (EESI) source for the online mass spectrometry analysis of organic aerosols, Environmental Science \& Technology 2013, DOI: 10.1021/es305199h.

[33] Kumbhani, S.; Longin, T.; Wingen, L. M.; Kidd, C.; Perraud, V.; Finlayson-Pitts, B. J. New mechanism of extractive electrospray ionization mass spectrometry for heterogeneous solid particles, Anal. Chem. 2018, DOI: 10.1021/acs.analchem.7b04164.

[34] Qi, L; Chen, M.-D.; Stefenelli, G.; Pospisilova, V.; Tong, Y.-D.; Bertrand, A.; Hueglin, C.; Rigler, M.; Ge, X.-L.; Baltensperger, U.; Prévôt, A. S. H.; Slowik, J. G. Organic aerosol source apportionment in Zurich using an extractive electrospray ionization time-of-flight mass spectrometer (EESI-TOF-MS) - Part 2: Biomass burning influences in winter, Atmos. Chem. Phys. 2019, DOI: 10.5194/acp-19-8037-2019

[35] Wang, R.; Groehn, A. J.; Zhu, L.; Dietiker, R.; Wegner, K.; Guenther, D.; Zenobi, R. On the mechanism of extractive electrospray ionization (EESI) in the dual-spray configuration, Anal. Bioanal. Chem. 2012, DOI: 10.1007/s00216-011-5471-8.

[36] Chen, H.; Venter, A.; Cooks, R. G. Extractive electrospray ionization for direct analysis of undiluted urine, milk and other complex mixtures without sample preparation, Chem. Commun. 2006, DOI: 10.1039/b602614a.

[37] Liu, C.; Zhang, X.; Xiao, S.; Jia, B.; Cui, S.; Shi, J.; Xu, N.; Xie, X.; Gu, H.; Chen, C. Detection of trace levels of lead in aqueous liquids using extractive electrospray ionization tandem mass spectrometry, Talanta, 2012, DOI: 10.1016/j.talanta.2012.06.048.

[38] Stefenelli, G.; Pospisilova, V; Lopez-Hilfiker, F. D.; Daellenbach, K. R.; Hüglin, C.; Tong, Y.; Baltensperger, U.; Prevot, A. S. H.; Slowik, J. G. Organic aerosol source apportionment in Zurich using extractive electrospray ionization time-of-flight mass spectrometry (EESI-TOF): Part I, biogenic influences and day/night chemistry in summer, Atmos. Chem. Phys. Discuss. 2019, DOI: 10.5194/acp-2019-361.

[39] Mollah, S.; Pris, A. D.; Johnson, S. K.; Gwizdala, A. B.; Houk, R. S. Identification of metal cations, metal complexes, and anions by electrospray mass spectrometry in the negative ion mode, Anal. Chem., 2000, DOI: $10.1021 /$ ac9908647.

[40] Hotta, H.; Mori, T.; Takahashi, A.; Kogure, Y.; Johno, K.; Umemura, T.; Tsunoda, K. Quantification of trace elements in natural samples by electrospray ionization mass spectrometry with a size-exclusion column based on the formation of metal-aminopolycarboxylate complexes, Anal. Chem. 2009, DOI: 10.1021/ac9006842, 2009.

[41] Xu, C.; Dodbiba, E.; Padivitage, N. L. T.; Breitbach, Z. S.; Armstrong, D. W. Metal cation detection in positive ion mode electrospray ionization mass spectrometry using a tetracationic salt as a gas-phase ion-pairing agent: evaluation of the effect of chelating agents on detection sensitivity, Rapid Commun. Mass Spectrom. 2012, DOI: $10.1002 / \mathrm{rcm} .6413$.

[42] Junninen, H.; Ehn, M.; Petaja, T.; Luosujarvi, L.; Kotiaho, T; Kostiainen, R.; Rohner, U.; Gonin, M.; Fuhrer, K.; Kulmala, M.; Worsnop, D. R. A high-resolution mass spectrometer to measure atmospheric ion composition, Atmos. Meas. Tech. 2010, DOI: 10.5194/amt-3-1039-2010.

[43] Berkel, G. J. V. Electrolytic deposition of metals on to the high-voltage contact in an electrospray emitter: implications for gas-phase ion formation, J. Mass Spectrom. 2000, DOI: 10.1002/10969888(200007)35:7<773::AID-JMS4>3.0.CO;2-6.

[44] Inczédy, J.; Lengyel, T.; Ure, A. M. Compendium on Analytical Nomenclature. Definitive Rules 1997, 3rd Ed. IUPAC, Blackwell Science, New York, NY, 1998. 